Case Reports
in Dermatology
Case Rep Dermatol 2020;12:98-106

DOI: 10.1159/000507916

Published online: May 15, 2020
(C) 2020 The Author(s)

Published by S. Karger AG, Basel

www.karger.com/cde

This article is licensed under the Creative Commons Attribution-NonCommercial 4.0 International License (CC BY-NC) (http://www.karger.com/Services/OpenAccessLicense). Usage and distribution for commercial purposes requires written permission.

\title{
Reflectance Confocal Microscopy of Pigmented Bowen's Disease: A Case Series of Difficult to Diagnose Lesions
}

\author{
Sara Mazzillia Reyes Gamo-Villegas ${ }^{b} \quad$ Ana Pampin-Franco ${ }^{b}$ \\ Jose Luis Lopez Estebaran ${ }^{\mathrm{b}}$ Fernando Pinedo ${ }^{c}$ Laura Vollono $^{\mathrm{a}}$ \\ Monia Di Prete Elena Campione $^{\mathrm{a}} \quad$ Salvador Gonzalez ${ }^{\mathrm{d}}$ \\ aDepartment of Dermatology, Tor Vergata Hospital, Rome, Italy; bermatology Service, \\ Fundation Alcorcon Hospital, Madrid, Spain; 'Department of Pathology, Fundation \\ Alcorcon Hospital, Madrid, Spain; dDepartment of Medicine and Medical Specialties,

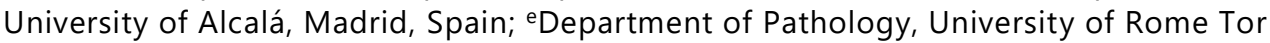 \\ Vergata, Rome, Italy
}

\section{Keywords}

Reflectance confocal microscopy · Pigmented Bowen's disease · Skin cancer

\begin{abstract}
Pigmented Bowen's disease is a rare variant of in situ squamous skin cell carcinoma. It mainly affects patients between 60 and 70 years of age. Its clinical features include welldemarcated, pigmented plaque arising in photo-exposed areas of the body. The bestkeratinocytes, hyperpigmentation of the epidermis with trans-epidermal elimination of melanin and dermal melanophages. Precise diagnosis is often difficult, both clinically and dermoscopically, as Bowen's disease is often mistaken with keratinocyte tumors such as solar lentigines, seborrheic keratosis, Bowenoid papulosis, pigmented basal cell characterized feature of the disease by histological examination is the presence of atypical 


\section{Case Reports in Dermatology}

Case Rep Dermatol 2020;12:98-106

DOI: $10.1159 / 000507916$

(C) 2020 The Author(s). Published by S. Karger AG, Basel www.karger.com/cde

Mazzilli et al.: Reflectance Confocal Microscopy of Pigmented Bowen's Disease

carcinoma, pigmented actinic keratosis; or even melanocytic lesions such as melanocytic nevus, pigmented epithelioid melanocytoma, and melanoma. Precise diagnosis often requires biopsy and histopathological examination of the tissue. Reflectance confocal microscopy is a noninvasive technique to diagnose pigmented skin lesions. To date, not much data are available regarding its use in the diagnosis of pigmented Bowen's disease. Herein, we report a well-represented case series of pigmented Bowen's disease imaged using dermoscopy and reflectance confocal microscopy.

\section{Introduction}

Pigmented Bowen's disease (pBD) is a rare variant of in situ squamous skin cell carcinoma of the skin that mainly affects patients between 60 and 70 years of age. pBD represents an uncommon (less than 2\%) variant of Bowen's disease, appearing a slow growing, flat, hyperpigmented, well-demarcated scaly plaque. Although it can be located in several areas of the body, it is most frequently located in sun-exposed regions of the skin [1]. This is a disease that is not always easy to distinguish from other skin diseases from a clinical and dermoscopic point of view. pBD can be easily confused with keratinocytic tumors such as solar lentigines, seborrheic keratosis, Bowenoid papulosis, pigmented basal cell carcinoma, pigmented actinic keratosis, as well as melanocytic lesions such as melanocytic nevus, pigmented epithelioid melanocytoma, and melanoma [2].

Dermoscopic criteria for pBD include glomerular, coiled, dotted or atypical vessels, blue homogeneous pigmentation, diffuse irregular pigmentation, amorphous brown or gray pigmentation, irregularly distributed granular blue-gray structures, peripheral brown globules, and irregularly distributed dots and globules, focal/multifocal hypopigmentation and pigmented scales, with variable accuracy rate [3-6]. A precise diagnosis of pBD often requires incisional biopsy. Histopathological examination of the excised tissue is characterized by epidermal disarray and atypical keratinocytes, hyperpigmentation of the epidermis with transepidermal elimination of melanin and dermal melanophages [2].

Reflectance confocal microscopy (RCM) is a noninvasive technique mostly used for differential diagnosis of pigmented, melanocytic and nonmelanocytic skin lesions. To date, few data are available regarding its use in the diagnosis of pBD [7-11].

\section{Case Series}

Here, we present the RCM findings of five histologically-proven pBD cases displaying challenging clinical and dermoscopic features. The potential of RCM to differentiate pBD from other pigmented lesions in elderly patients is high. However, it requires a precise description of well-diagnosed cases, which is the intent of the present report. The clinical, dermoscopic, and RCM findings of the five cases are listed in Table 1.

The mean age at diagnosis was 54 years old. The main dermoscopic finding was presence of brownish, structure-less areas. One patient presented one pink lesion with small brown islands. A major pitfall of RCM observation was the presence of atypical honeycomb pattern 


\section{Case Reports in Dermatology}

Case Rep Dermatol 2020;12:98-106

DOI: $10.1159 / 000507916$

(C) 2020 The Author(s). Published by S. Karger AG, Basel www.karger.com/cde

Mazzilli et al.: Reflectance Confocal Microscopy of Pigmented Bowen's Disease

with elongated keratinocytes with several side and shape variations in cell and nuclear morphology, dyskeratotic cells (dashed dark circle) related to a retraction halo. This was well represented in the majority of the cases reported.

In particular, two of the pBD cases reported here displayed dendritic and spindly cells in affected areas (Fig. 1, 2, 3, 4), the scalp and the nose. These observations had been previously reported by others $[4,12,8]$. The differentiating element that enabled us to discard melanoma as diagnosis, was the presence of small dermal papillae in the junction.

Regarding diskeratotic cells, we observed a large frequency of atypical keratinocytes that could represent a second type of targetoid cells, characterized by a dark center and a bright rim surrounded by a dark halo [12].

Another clear RCM feature was the presence of "button-hole signs", corresponding to the presence of tortuous vessels arranged perpendicular to the epidermal layer (Fig. 5). This was particularly apparent in one case of nailfold squamous cell carcinoma reported in this case series as well as elsewhere regarding its clinical and dermoscopic findings [13].

\section{Discussion}

RCM provides clues that enable distinguishing between pBD and melanoma. These are: presence of atypical honeycomb pattern, atypical keratinocytes of different sizes and shapes, and "button-hole signs" consistent with tortuous blood vessels. A potential diagnostic point of discussion is the presence of numerous bright, large, round or dendritic cells infiltrating the epidermis, as previously observed [7, 9]. Recently, three challenging cases of pigmented Bowen's disease were reported and wrongly diagnosed as melanoma due to the high density of dendritic cells observed using RCM [8]. Along the same line, the efficacy of combined use of dermoscopy and RCM for evaluating pBD highlighted the atypical honeycomb pattern at the spinous layer contain cells and nuclei with various shapes and sizes [6]. Another study analyzed the pitfalls of RCM to diagnose pigmented squamous cell carcinoma, assessing the presence of parakeratosis, irregular honeycomb pattern at the spinous granular layer, spindleshaped cells with dendritic branches infiltrating the epidermis, and dilated looped blood vessels [10]. In this cases series, and within its size limitation, we have confirmed the presence of an atypical honeycomb pattern and the presence of atypical, dyskeratotic and spindles and dendritic cells as the most relevant features in pBD.

We have also assessed the presence of a second type of targetoid cells in the context of dyskeratotic cells. Additional features observed included dermal button-hole sign and parakeratosis.

\section{Conclusion}

This work underlines the potential of RCM as an additional ancillary tool for the clinical diagnosis of pBD exhibiting its challenging dermoscopic features. Further studies are needed in order to confirm our preliminary observations. 


\section{Case Reports in Dermatology}

Case Rep Dermatol 2020;12:98-106

DOI: $10.1159 / 000507916$

(C)

(C) 2020 The Author(s). Published by S. Karger AG, Basel www.karger.com/cde

Mazzilli et al.: Reflectance Confocal Microscopy of Pigmented Bowen's Disease

\section{Statement of Ethics}

The subjects have given their informed consents to publish their case (including images publication), and the study protocol has been approved by the institute's committee on human research.

\section{Disclosure Statement}

The authors have no conflicts of interest to disclose.

\section{Funding Sources}

This study received no funding.

\section{Author Contributions}

S.M, R.G.V., A.P.F., J.L.L.E., F.P., L.V., M.D.P., E.C., and S.G. have contributed to the conception and design of the work; the acquisition, analysis, and interpretation of the data; and draft and revision of the manuscript. All authors have revised and approved the final version of the manuscript, and make themselves responsible for the accuracy and integrity of the work as a whole.

\section{References}

1 Zhou LL, Mistry N. Pigmented Bowen disease. CMAJ. 2017 Nov 27;189(47):E1462. https://doi.org/10.1503/cmaj.170810.

2 Mota AN, Piñeiro-Maceira J, Alves MF, Tarazona MJ. Pigmented Bowen’s disease. An Bras Dermatol. 2014 Sep-Oct;89(5):825-7.

3 Bugatti L, Filosa G, De Angelis R. Dermoscopic observation of Bowen's disease. J Eur Acad Dermatol Venereol. 2004 Sep;18(5):572-4.

4 Stante M, de Giorgi V, Massi D, Chiarugi A, Carli P. Pigmented Bowen's disease mimicking cutaneous melanoma: clinical and dermoscopic aspects. Dermatol Surg. 2004 Apr;30(4 Pt 1):541-4.

5 Zalaudek I, Argenziano G, Leinweber B, Citarella L, Hofmann-Wellenhof R, Malvehy J, et al. Dermoscopy of Bowen's disease. Br J Dermatol. 2004 Jun;150(6):1112-6.

6 Cameron A, Rosendahl C, Tschandl P, Riedl E, Kittler H. Dermatoscopy of pigmented Bowen's disease. J Am Acad Dermatol. 2010 Apr;62(4):597-604.

7 Nguyen KP, Peppelman M, Hoogedoorn L, Van Erp PE, Gerritsen MP. The current role of in vivo reflectance confocal microscopy within the continuum of actinic keratosis and squamous cell carcinoma: a systematic review. Eur J Dermatol. 2016 Dec;26(6):549-65.

8 Debarbieux S, Perrot JL, Cinotti E, Labeille B, Fontaine J, Douchet C, et al. Reflectance confocal microscopy of Pigmented Bowen's disease: misleading dendritic cells. Skin Research and Technology. 2017 Feb;23(1):1268. https://doi.org/10.1111/srt.12304.

9 Karaarslan I, Tepret S, Yildiz S, Yaman B, Ozdemir F. The role of reflectance confocal microscopy in a case of Bowen's disease difficult to diagnose. Dermatol Pract Concept. 2018 Jan;8(1):63-5.

10 Shahriari N, Grant-Kels JM, Rabinovitz HS, Oliviero M, Scope A. Reflectance Confocal Microscopy Criteria of Pigmented Squamous Cell Carcinoma In Situ. Am J Dermatopathol. 2018 Mar;40(3):173-9. 


\section{Case Reports in Dermatology} www.karger.com/cde

11 Ianoși SL, Batani A, Ilie MA, Tampa M, Georgescu SR, Zurac S, et al. Non-invasive imaging techniques for the in vivo diagnosis of Bowen's disease: three case reports. Oncol Lett. 2019 May;17(5):4094-101.

12 Ulrich M, Kanitakis J, González S, Lange-Asschenfeldt S, Stockfleth E, Roewert-Huber J. Evaluation of Bowen disease by in vivo reflectance confocal microscopy. Br J Dermatol. 2012 Feb;166(2):451-3.

13 Mazzilli S, Terenzio C, Diluvio L, Vollono L, Gonzalez S, Di Prete M, et al. Dermoscopy and Reflectance Confocal Microscopy in the Diagnosis and Management of Nail Fold Squamous Cell Carcinoma. J Med Life. Forthcoming 2020.
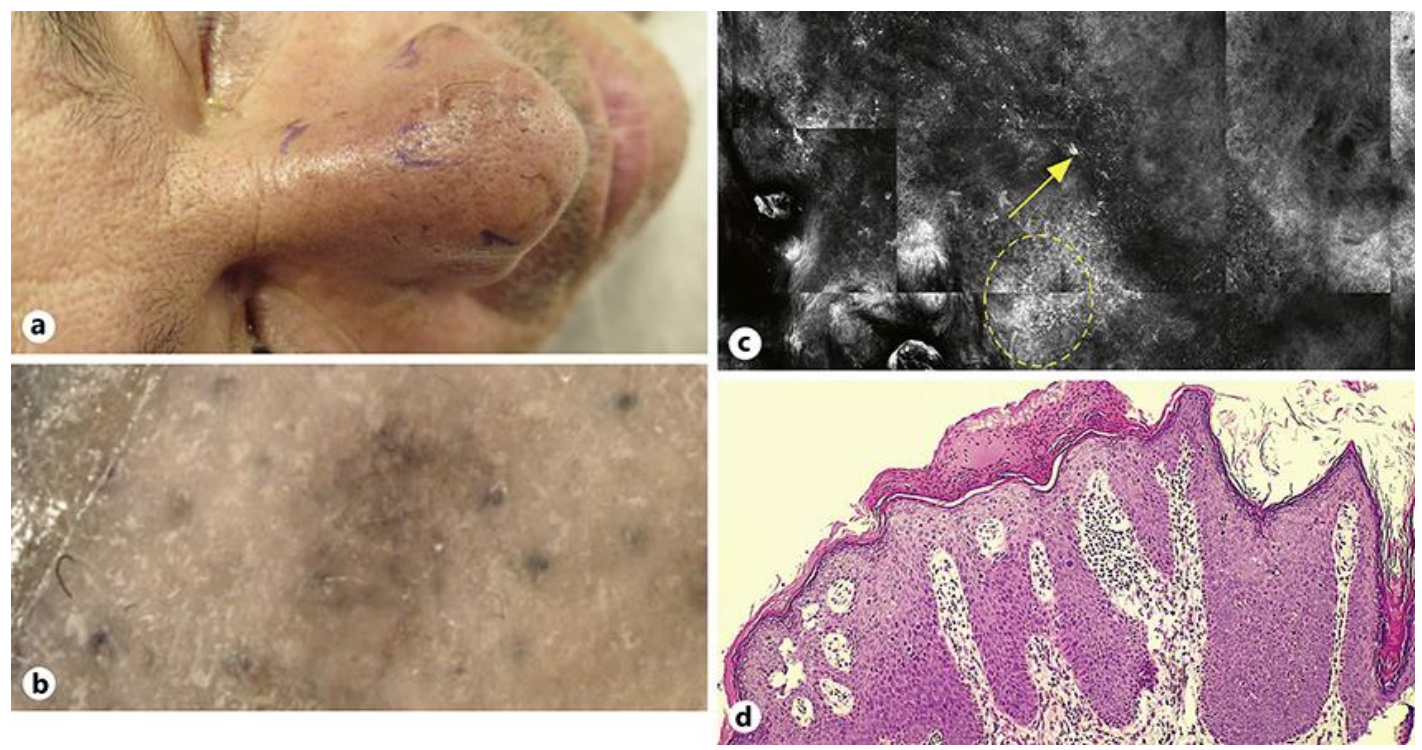

Fig. 1. a Clinical image of an ill demarcated brownish scale plaque located on the nose. b Dermoscopy image underlines brown irregular pigmentation in the context of structureless area. c RCM (mosaic, $6 \times 6 \mathrm{~mm}$ ) reveals markedly atypical honeycomb or disarranged pattern (yellow dashed ellipse), round nucleated cells (dyskeratotic keratinocytes) at the spino-granular layer and melanophages (yellow arrow). d Histopathology reveals full-thickness keratinocytes atypia, acanthosis, and moderate mitosis augmentation $(\mathrm{H} / \mathrm{E} \times 100)$. 


\section{Case Reports in Dermatology}

Case Rep Dermatol 2020;12:98-106

DOI: $10.1159 / 000507916$

(C) 2020 The Author(s). Published by S. Karger AG, Basel www.karger.com/cde

Mazzilli et al.: Reflectance Confocal Microscopy of Pigmented Bowen's Disease
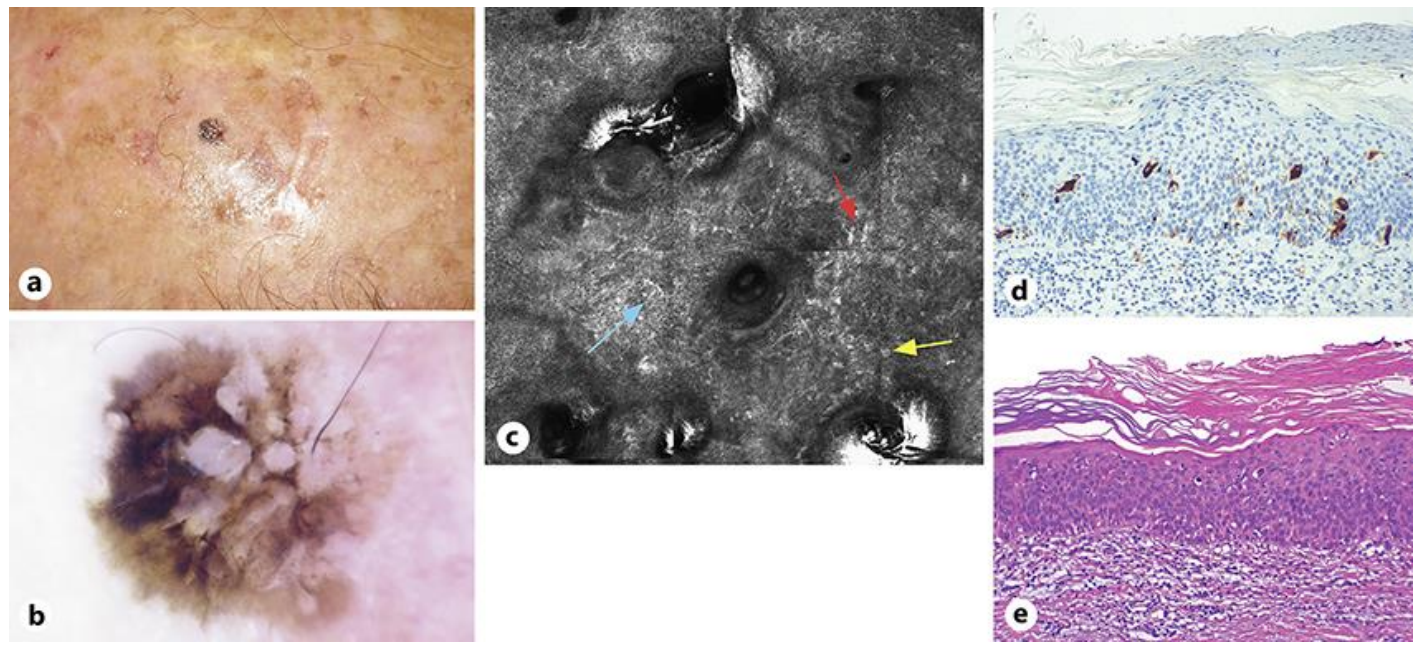

Fig. 2. a Clinical image of brownish large macule located on the scalp. b Dermoscopy shows brown pigment network diversity with white structureless areas. c RCM reveals several dyskeratotic cells (large, targetoid cells with dark round center) (yellow arrow) at the spinous-granular layer (black circle); in particular the atypical honeycomb pattern is characterized by the presence of several dendritic cells (blue arrow) and spindle-shaped cells (red arrow). $\mathbf{d}$ Histopathology showing a section stained for MELAN-A that correlates melanocytes with dendritic and spindly morphology. e H/E histology shows parakeratosis and full-thickness atypia of epidermis with acanthosis and increased melanin pigmentation. 


\section{Case Reports in Dermatology}

(C) 2020 The Author(s). Published by S. Karger AG, Basel

Mazzilli et al.: Reflectance Confocal Microscopy of Pigmented Bowen's Disease www.karger.com/cde
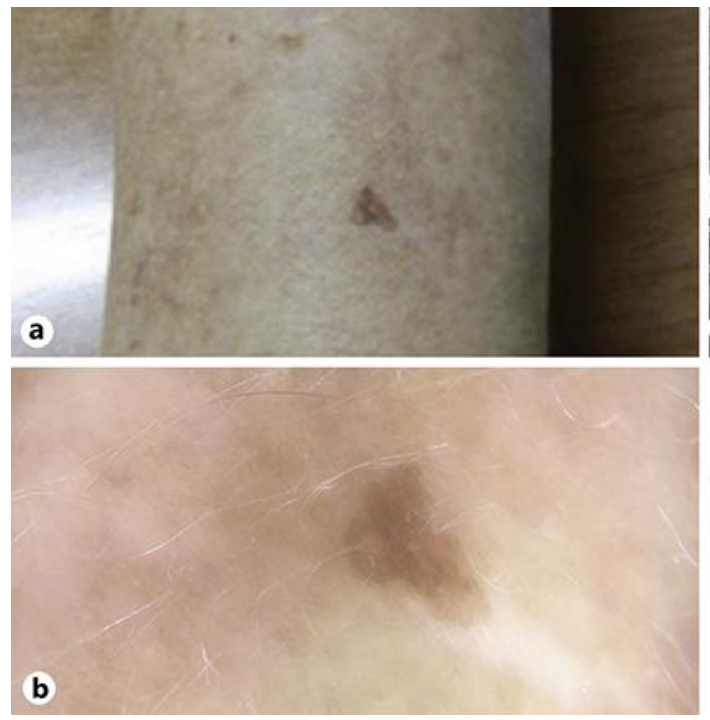
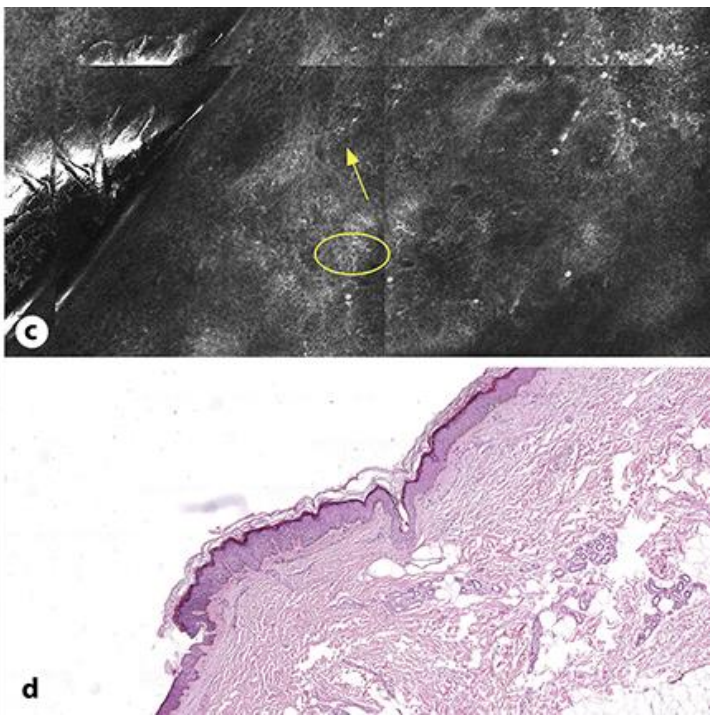

Fig. 3. a Clinical image of pigmented lesion located on the arm. b Dermoscopy showing a slightly brownish, structure-less area. c RCM shows atypical honeycomb (yellow circle) with dark atypical keratinocytes (dyskeratotic keratinocytes, yellow arrow) at the spinous-granular layer; a ringed pattern composed of small close-set edged papillae at the DEJ is also seen. $\mathbf{d} \mathrm{H} / \mathrm{E}$ histopathology reveals full-thickness atypia of epidermis with acanthosis and increased melanin pigmentation at the basal cell layer. 


\section{Case Reports in Dermatology}
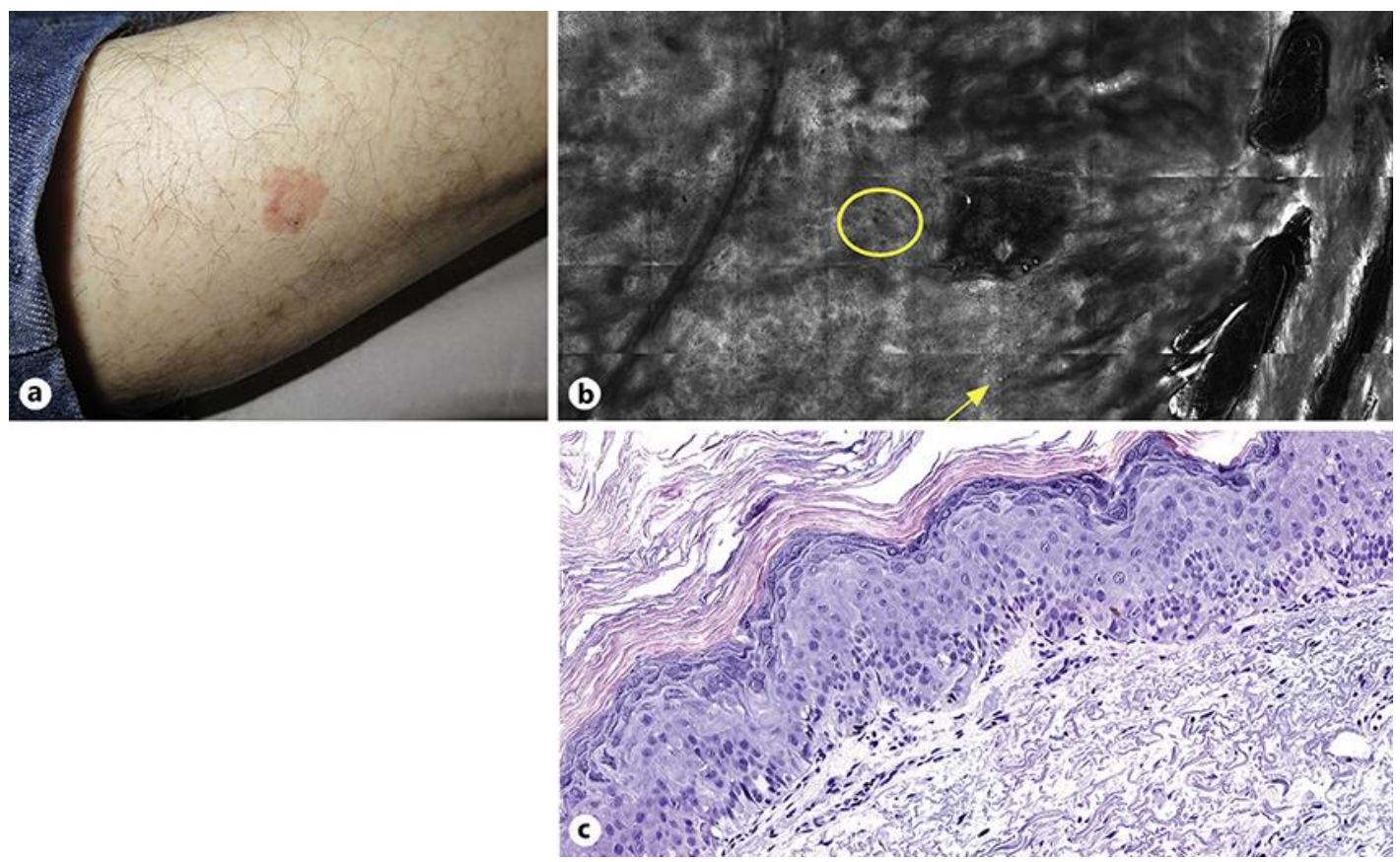

Fig. 4. a Clinical image of slightly pigmented red macula located on the leg. b RCM illustrates the atypical honeycomb pattern, atypical keratinocytes and shapes as well as small round cells (yellow arrow) at the epidermal layer. Round dermo-epidermal papillae (yellow circle) can also be seen. c H/E histology reveals full-thickness keratinocyte atypia, apoptotic bodies, mild mitosis, and acanthosis.
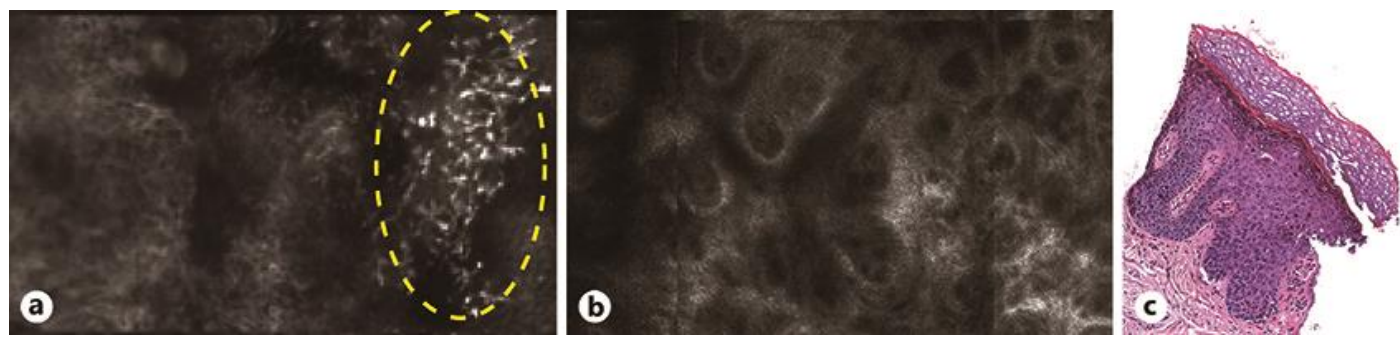

Fig. 5. a RCM reveals a pigmented nodular lesion located on the nailfold displaying atypical honeycomb within acanthotic epidermis, containing numerous stellated figures that may correspond to sweat-related structures (dashed circle). b RCM of another section of the lesion reveals the presence of button-hole signs (vessels perpendicular to the epidermis). $\mathrm{cH} / \mathrm{E}$ histopathology confirming the pBD diagnosis. 


\section{Case Reports in Dermatology}

\begin{tabular}{l|l}
\hline Case Rep Dermatol 2020;12:98-106 \\
\hline DOI: 10.1159/000507916 & $\begin{array}{l}\text { (c) 2020 The Author(s). Published by S. Karger AG, Basel } \\
\text { www.karger.com/cde }\end{array}$ \\
\hline
\end{tabular}

Mazzilli et al.: Reflectance Confocal Microscopy of Pigmented Bowen's Disease

Table 1. Patient series: clinical, dermoscopic, and confocal characteristics

\begin{tabular}{|c|c|c|c|c|}
\hline Patient age & Gender & $\begin{array}{l}\text { Clinical lo- } \\
\text { cation }\end{array}$ & Dermoscopic characteristics & RCM features \\
\hline 56 years old & male & nose & Brownish structureless areas & $\begin{array}{l}\text { Atypical honeycomb pattern, dyskeratosis, } \\
\text { and dendritic cells }\end{array}$ \\
\hline 65 years old & male & scalp & $\begin{array}{l}\text { Brownish structureless areas and dif- } \\
\text { fuse irregular pigmentation }\end{array}$ & $\begin{array}{l}\text { Atypical honeycomb pattern, dendritic cells, } \\
\text { spindle cells, and targetoid dyskeratotic cells }\end{array}$ \\
\hline 60 years old & female & forearm & Brownish structureless areas & $\begin{array}{l}\text { Atypical honeycomb pattern, dendritic cells, } \\
\text { small edged papillae }\end{array}$ \\
\hline 48 years old & male & nailfold & $\begin{array}{l}\text { Brownish area with peripheral brown } \\
\text { globules }\end{array}$ & $\begin{array}{l}\text { Atypical honeycomb pattern, button-hole } \\
\text { sign }\end{array}$ \\
\hline 54 years old & male & leg & Pink-brownish areas & $\begin{array}{l}\text { Atypical honeycombed pattern, targetoid } \\
\text { cells, small round edged papillae }\end{array}$ \\
\hline
\end{tabular}

